\title{
UJI AKTIVITAS ANTIDIARE EKSTRAK ETANOL DAUN CIPLUKAN (Physallis minima L.) TERHADAP MENICT JANTAN (Mus musculus)
}

\author{
Evi Depiana Gultom ${ }^{*}$, Robiatun Rambe ${ }^{2}$, Ratih Paramitha ${ }^{2}$, Ovalina Sylvia Br. Ginting $^{2}$ \\ ${ }^{1}$ Institusi Deli Tua Deli Husada, Deli Serdang, Indonesia \\ ${ }^{2}$ Universitas Haji Sumatea Utara, Medan, Indonesia \\ *E-mail: evidepiana1@gmail.com
}

\begin{abstract}
Abstrak
Daun ciplukan (Physallis minima L.) merupakan tanaman herbal yang mengandung flavonoid, saponin, alkaloid dan tanin. Senyawa tanin bersifat adstringent untuk mencegah disentri dan diare. Tujuan penelitian ini adalah untuk menguji efektivitas antidiare ekstrak etanol daun ciplukan pada mencit jantan(Mus musculus). Penelitian ini dilakukan secara in vivo dengan menggunakan hewan mencit. Pengujian aktivitas antidiare ekstrak etanol daun ciplukan (EEDC) diinduksi dengan minyak jarak $0,5 \mathrm{ml}$ dan diamati parameter yang terdiri dari, onset, frekuensi diare, konsistensi dan berat feses, serta durasi diare setiap 30 menit selama 5 jam. Metode antimotilitas dilakukan untuk mengukur panjang usus yang dilintasi marker. Data dianalisis dengan menggunakan uji One-way ANOVA dan Post Hoc Tuckey. Uji efek antidiare EEDC pada mencit jantan menunjukkan bahwa dosis 50,100, 200 dan $400 \mathrm{mg} / \mathrm{kg}$ bb memiliki efek sebagai anti diare dengan menunjukkan perbedaan signifikan dengan kontrol negatif $(p<0,05)$. Uji efek antidiare dengan metode induksi oleh minyak jarak menunjukkan bahwa EEDC dosis $200 \mathrm{mg} / \mathrm{kg}$ bb dan $400 \mathrm{mg} / \mathrm{kg}$ bb efektif sebagai antidiare dan tidak berbeda signifikan $(\mathrm{p}>0,05)$ dengan kontrol positif sedangkan metode antimotilitas EEDC dosis $400 \mathrm{mg} / \mathrm{kg}$ bb efektif sebagai antidiare karena tidak memiliki perbedaan siginifikan ( $\mathrm{p}>0,05)$ dengan kontrol positif.
\end{abstract}

Kata kunci : antidiare, antimotilitas, ekstrak etanol daun ciplukan dan minyak jarak, tinta cina, in vivo

\begin{abstract}
Ciplukan leaves (Physallis minima L.) is an herbal plant that contains flavonoids, saponins, alkaloids and tannins. Tannin compounds are adstringent to prevent dysentery and diarrhea. The purpose of this study was to test the antidiarrheal effectiveness of the ethanol extract of ciplukan leaves in male mice (Mus musculus). This research was conducted in vivo using mice. The antidiarrheal activity test of ciplukan leaf ethanol extract (EEDC) was induced with $0.5 \mathrm{ml}$ castor oil and the observed parameters consisted of, onset, frequency of diarrhea, consistency and weight of feces, and duration of diarrhea every 30 minutes for 5 hours. The antimotility method was used to measure the length of the intestine which was traversed by the marker. Data were analyzed using One-way ANOVA and Post Hoc Tuckey tests. The EEDC antidiarrheal effect test in mice showed that doses of 50,100, 200 and $400 \mathrm{mg} / \mathrm{kg} \mathrm{BW}$ had an anti-diarrheal effect by showing significant differences with negative controls $(p<0.05)$. The antidiarrheal effect test with the induction method by castor oil showed that the EEDC dosage of $200 \mathrm{mg} / \mathrm{kg} \mathrm{bw}$ and $400 \mathrm{mg} / \mathrm{kg}$ bw was effective as anti-diarrhea and was not significantly different $(p>0.05)$ with the positive control, while the EEDC antimotility method was $400 \mathrm{mg} / \mathrm{kg}$ bb was effective as an antidiarrheal because it had no significant difference $(p>0.05)$ with positive control.
\end{abstract}


Key words: antidiarrheal, antimotility, ethanol extract of ciplukan leaves and castor oil, chinese ink, in vivo

\section{Pendahuluan}

Ada lebih dari 30.000 jenis tumbuhan dibumi nusantara ini, dan lebih dari 1000 jenis telah diketahui manfaatnya untuk pengobatan (Anonim, 2004.) Salah satu tanamanan obat yang sangat sering kita jumpai tapi belum banyak dimanfaatkan secara luas adalah tanaman ciplukan (Physallis minima L). Ciplukan ini merupakan tumbuhan herba atau semak semusim, tumbuh ditanah kosong yang tidak terlalu banyak air, pinggir selokan, pinggir kebun, pinggir sawah. Secara empiris tanaman ciplukan (Physallis minima L) dapat mengobati penyakit diare (Nita Fajaryanti dan Nunik Ida Kurniawati, 2018). Berdasarkan informasi yang diperoleh peneliti dari beberapa daerah, bahwa ciplukan sering digunakan sebagai obat tradisional. Upaya masyarakat untuk mengobati diare menggunakan tanaman ciplukan (Physallis minima L) dengan merebus daun ciplukan (Physallis minima L) 25-30 lembar dengan $200 \mathrm{ml}$ air hingga menjadi $100 \mathrm{ml}$ air selama 15 menit disaring lalu diminum 1-2 kali sehari setiap pagi dan sore hari (Hariana, 2007).

Tumbuhan ciplukan memiliki berbagai kandungan kimia, yang sudah diketahui, antara lain chlorogenik acid, asam sitrun, dan fisalin, flavonoid, saponin, polifenol, dan buahnya mengandung asam malat, alkaloid, tanin, kriptoxantin, vitamin $\mathrm{C}$, dan gula sedangkan bijinya mengandung elaidic acid. Bagian tanaman yang sering digunakan adalah akar, daun dan buah (Joko Suryo, 2010). Tanaman ciplukan memiliki kandungan utama yaitu flavonoid dan tanin. Tanin bersifat sebagai adstringents dimana zat ini menyebabkan perapatan dan penciutan lapisan sel sehingga menghambat sekresi jaringan (Muschler, 1999). Dan flavonoid sebagai antidiare adalah dengan menghambat pelepasan asetilkolin pada saluran cerna (Luterrdort, 1989).

Diare adalah suatu gejala klinis dari gangguan pencernaan (usus) yang ditandai dengan bertambahnya frekuensi defekasi lebih dari biasanya dan berulang-ulang ( lebih dari $3 \mathrm{x}$ sehari) yang disertai adanya perubahan bentuk dan konsitensi feses menjadi lunak atau cair (Aulia Ajizah,2004). Pada diare hebat seringkali disertai muntah-muntah, tubuh kehilangaan banyak cairan dengan garam-garam terutama natrium dan kalium. Salah satu dari efek samping terjadinya diare adalah dehidrasi.Hal ini disebabkan, pada saat diare terjadi kehilangan cairan dan elektrolit, sehingga tubuh akan mengalami dehidrasi. Jikakeadaan ini tidak ditangani segera, bisa berakhir dengan syok atau kematian (Soegijanto, 2004). Penyebab penyakit diare diantara lain adalah akibat virus, akibat bakteri, diare parasiter dan pengaruh psikis (Citra Tarannita, 2006).

Profil Kesehatan Provinsi Sumatera Utara pada tahun 2014 melaporkan jumlah perkiraan kasus sebanyak 294.6111 kasus yang ditemukan dan ditangani sebanyak 240.303, sehingga angka penderita diare per 1000 penduduk mencapai 17,45. Data Dinas Kesehatan Sumatera Utara, Januari sampai maret 2014, menyatakan bahwa ada 3.796 penderita usia dibawah 5 tahun dari Medan dan pada tahun 2016 jumlah penderita diare semua umur (SU) yang dilayani di sarana kesehatan sebanyak 3.176.079 penderita dan terjadi peningkatan pada tahun 2017 yaitu menjadi 4.274 .790 penderita atau $60,4 \%$ dari perkiraan diare di sarana kesehatan. Insiden diare semua umur secara nasional 270/1000 penduduk (Kemenkes RI, 2017).

Tindakan umum mengatasi diare ditunjukkan pada tindakan sanitasi yang cermat dalam kebersihan, mencuci tangan dengan bersih sebelum makan atau mengolah makanan. Selain itu, untuk mengatasi penyakit diare dapat jugamengkonsumsi obat-obat anti diare (Nita Fajaryanti dan Nunik Ida Kurniawati, 2018). Obat-obat yang digunakan dalam pengobatan diare dikelompokkan menjadi beberapa kategori yaitu, antimotilitas, adsorben. Antisekresi, antibiotik, enzim, dan mikroflora usus (Sukandar, 2008).Mengatasi pengobatan penyakit diare dengan obat anti diare dapat menyebabkan efek samping 
seperti mual, muntah, dan alergi. Sehingga pengobatan secara obat tradisional menggunakan bahan alami dari ramuan tanaman obat masih banyak digunakan oleh masyarakat. Semakin berkembangnya jenis obat-obatan untuk mengobati diare, yang makin membuat biaya semakin mahal, maka diperlukan suatu bahan berkhasiat yang dalam kehidupan sehari-hari, mudah didapat, murah cukup berkhasiat, dan efek sampingnya tidak sebesar obat-obat sintesis (Citra Tarannita dkk, 2006).

Penelitian uji efek antidiare dari ekstrak daun ciplukan sudah pernah dilakukan oleh saudari Nita Fajaryanti et.al., 2018 "Efek Antidiare infusa daun ciplukan (Physallis anguleta L.) pada mencit jantan putih (Mus musculus) yang terpapar oleum ricini" dengan metode Defekasi dan hasil penelitian yang dilakukan saudari Nita Fajaryanti et.al., 2018 menunjukkan bahwa ekstrak etanol dari daun ciplukan memiliki efek sebagai antidiare.Dan adapun penelitian yang dilakukan oleh saudara Luki Alkautsari (2015) "Uji aktivitas Antibakteri ekstrak daun ciplukan (Physallis minima L) terhadap bakteri pertumbuhan bakteri Salmonella sp. menunjukkan Daun ciplukan berpengaruh terhadap pertumbuhan bakteri Salmonella $s p$, dimana bakteri ini dapat menyebabkan diare (Luki Alkautsari, 2016).

Berdasarkan uraian diatas peneliti tertarik ingin melakukan uji aktivitas antidiare ekstrak daun ciplukan (Physallis minima L.) terhadap mencit jantan (Mus musculus) dengan metode farmakologi yang berbeda.

\section{Metode Penelitian}

Penelitian ini dilakukan secara eksperimental dengan tahapan penelitian yaitu penyiapan sampel, pembuatan ekstrak, penyiapan hewan dan pengujian efek antidiare pada hewan percobaan. Data hasil penelitian dianalisis secara ANOVA (analisis of variasi) dan dilanjutkan dengan uji beda Duncan menggunakan program SPSS (Statisyikal Prosuct and Service Solution) versi 18.0.

\section{Lokasi Penelitian}

Penelitian dilakukan di Laboratorium Stikes Nurliana Medan.

\section{Alat dan bahan}

a. Alat-alat

Alat-alat yang digunakan dalam penelitian ini adalah alat-alat gelas laboratorium, alumunium foil,cawan porselen, kaca object (object glass), kaca penutup (deck glass), kandang hewan, kain flanel, meja bedah hewan, mikroskop, neraca hewan (Presica), neraca listrik (Vibra), oral sonde, lumpang, stamfer, kertas saring, seperangkat alat bedah hewan, spuit $1 \mathrm{ml}$ (Terumo), Pipet tetes, rotary evaporator.

\section{b. Bahan}

Bahan tumbuhan yang digunakan pada penelitian ini adalah daun ciplukan, Bahan yang digunakan adalah minyak jarak, tinta cina, Na-CMC, tablet Lodia (sanbe), dan semua bahan kimia yang digunakan berkualitas pro analisis kecuali dinyatakan lain adalah kloralhidrat, etanol teknis (96\%), pereaksi Bouchardat, pereaksi Dragendroff, pereaksi Meyer, besi (III) klorida, timbal (II) asetat, amil alkohol, asam klorida, serbuk Magnesium, akuades.

\section{Hewan uji}

Hewan yang digunakan adalah Mencit jantan (Mus muculus)diperoleh dari Kampus Universitas Islam Negeri Sumatera Utara.

\section{Penyiapan bahan tumbuhan}

\section{a. Pengumpulan bahan tumbuhan}

Daun ciplukan diambil dari Desa Sayurmatinggi, Kecamatan Sayurmatinggi, Kabupaten Tapanuli Selatan, Provinsi Sumatera Utara. 


\section{b. Identifikasi bahan tumbuhan}

Identifikasi sampel (daun) dilakukan di Herbarium Medanese (MEDA) Fakultas Matematika dan Ilmu Pengetahuan Alam (MIPA) Universitas Sumatera Utara.

\section{c. Pengolahan tumbuhan}

Daun ciplukan dikumpulkan, dicuci dari pengotor dengan air mengalir hingga bersih, ditiriskan, selanjutnya dirajang sampai ukuran terkecil, kemudian dikeringkan dibawah sinar matahari hingga rapuh.

\section{Pemeriksaan karakteristik simplisia}

Pemeriksaan karakterisasi simplisia meliputi pemeriksaan makroskopik, mikroskopik, penetapan kadar air, penetapan kadar sari larut dalam air, penetapan kadar sari larutbdalam etanol, penetapan kadar abu total, dan penetapan kadar abu tidak larut dalam asam (Ditjen POM, 1997).

\section{a. Uji kadar air}

Bersihkan tabung penerima dan pendingin dengan asam pencuci, bilas dengan air, keringkan dalam lemari pengering. Ke dalam labu kering dimasukkan sejumlah zat yang ditimbang seksama yang diperkirakan mengandung $2 \mathrm{ml}$ sampai $4 \mathrm{ml}$ air. Jika zat berupa pasta, timbang dalam sehelai lembaran logam dengan ukuran yang sesuai dengen leher labu. Untuk zat yang dapat menyebabkan gejolak mendadak, tambahkan pasir kering yang telah dicuci secukupnya hingga menutupi dasar labu atau sejumlah tabung kapiler, panjang lebih kurang $100 \mathrm{~mm}$ yang salah satu ujung nya tertutup. Masukkan lebih kurang $200 \mathrm{ml}$ toluen kedalam labu, hubungkan alat. Tuang toluen kedalam tabung penerima melalui alat pendingin. Panaskan labu hati-hati selama 15 menit.

Setelah toluene mulai mendidih, suling dengan kecepatan lebih kurang 2 tetes tiap detik, hingga sebagian besar air tersuling. Kemudian naikkan kecepatan penyulingan hingga 4 tetes tiap detik. Setelah semua air tersuling, cuci bagian dalam pendingin dengan toluene, sambil dibersihkan dengan sikat tabung yang disambungkan pada kawat tembaga dan telah dibasahi dengan toluene. Lanjutkan penyulingan selama 5 menit. Biarkan tabung penerima mendingin hingga suhu kamar. Jika ada tetesan air yang melekat pada dinding tabung penerima, gosok dengan karet yang diikatkan pada sebuah kawat air tmemisah sempurna, baca volume air. Hitung kadar air dalam \% (Depkes RI, 2000).

\section{b. Uji kadar abu total}

Sebanyak 2 gram ekstrak kering di timbang, dimasukkan kedalam krus porselin yang telah dipijarkan dan ditara, diratakan.Pijarkan pelahan-lahan hingga arang habis, didinginkan dan ditimbang. Jika dengan cara ini arang tidak dapat dihilangkan, tambahkan air panas, saring melalui kertas saring bebas abu, pijarkan sisa dan kertas saring dalam krus yang sama. Masukkan filtrat kedalam krus, uapkan setelah itu pijarkan hingga bobot tetap, timbang. Hitung kadar abu terhadap bahan yang telah dikeringkan diudara (Depkes RI, 2000).

\section{c. Uji kadar abu yang tidak larut asam}

Abu yang diperoleh pada penetapan kadar abu, dididihkan selama $25 \mathrm{ml}$ asam klorida encer selama 5 menit, kumpulkan bagian yang tidak larut dalam asam. Saring melalui kurs kaca masir atau kertas saring bebas abu, cuci dengan air panas, pijarkan hingga bobot tetap, lalu ditimbang. Hitung kadar abu yang tidak larut dalam asam terhadap bahan yang telah dikeringkan diudara (Depkes RI, 2000).

\section{d. Penetapan kadar sari yang larut dalam air}

Sebanyak $5 \mathrm{~g}$ serbuk simplisia, dimaserasi selama 24 jam dalam $100 \mathrm{ml}$ airkloroform (2,5 ml kloroform dalam air suling sampai 1 liter) dalam labu bersumbat sambil dikocok sesekali selama 6 jam pertama, kemudian dibiarkan selama 18 jam, lalu disaring. Sejumlah $20 \mathrm{ml}$ filtrat pertama diuapkan sampai kering dalam cawan penguap yang berdasar rata yang telah ditara dan sisa dipanaskan pada suhu $105^{\circ} \mathrm{C}$ sampai diperoleh bobot tetap.Kadar sari yang larut dalam air dihitung terhadap bahan yang telah dikeringkan (Ditjen POM, 1995). 


\section{e. Penetapan kadar sari yang larut dalam etanol}

Sebanyak $5 \mathrm{~g}$ serbuk simplisia dimaserasi selama 24 jam dalam $100 \mathrm{ml}$ etanol 96\% dalam labu bersumbat sambil dikocok sesekali selama 6 jam pertama, kemudian dibiarkan selama 18 jam. Larutan tersebut disaring cepat untuk menghindari penguapan etanol.Sejumlah $20 \mathrm{ml}$ filtrat diuapkan sampai kering dalam cawan penguap yang berdasar rata yang telah dipanaskan dan ditara.Sisa dipanaskan pada suhu $105^{\circ} \mathrm{C}$ sampai diperoleh bobot tetap. Kadar sari yang larut dalam etanol 96\% dihitung terhadap bahan yang telah dikeringkan (Ditjen POM, 1995).

\section{Skrining fitokimia simplisia dan EEDC}

Skrinning fitokimia simplisia daun ceplukan meliputi pemeriksaan senyawa alkaloid, saponin, flavonoid, tanin, glikosida.

\section{a. Pemeriksaan alkaloid}

Serbuk simplisia ditimbang sebanyak $0,5 \mathrm{~g}$ kemudian ditambahkan $1 \mathrm{ml}$ asam klorida $2 \mathrm{~N}$ dan $9 \mathrm{ml}$ air suling, dipanaskan diatas penangas air selama 2 menit, di dinginkan lalu disaring. Filtrat dipakai untuk percobaan berikut :

1. diambil 3 tetes filtrat, lalu tambahkan 2 tetes pereaksi Meyer

2. diambil 3 tetes filtrat, lalu tambahkan 2 tetes pereaksi Bouchardat

3. diambil 3 tetes filtrat, lalu tambahkan pereaksi dargendorff. Alkaloida

dianggap positif apabila terjadi endapan atau paling sedikit dua atau tiga dari percobaan diatas (Ditjen POM, 1995).

\section{b. Pemeriksaan saponin}

Sebanyak 0,5 g simplisia dimasukkan kedalam tabung reaksi dan ditambahkan 10 $\mathrm{ml}$ air panas, didinginkan kemudian dikocok kut-kuat selama 10 detik, timbul busa yang mantap tidak kurang dari 10 menit setinggi 1 sampai $10 \mathrm{~cm}$, pada penambahan 1 tetes asam klorida 2N, buih tidak hilang (Ditjen POM, 1995).

\section{c. Pemeriksaan flavonoid}

Sebanyak $10 \mathrm{~g}$ serbuk simplisia kemudian ditambahkan $10 \mathrm{ml}$ air panas, didihkan selama 5 menit dan disaring dalam keadaan panas, filtrat yang diperoleh kemudian diambil $5 \mathrm{ml}$ lalu ditambahkan $0,1 \mathrm{~g}$ serbuk $\mathrm{Mg}$ dan $1 \mathrm{ml}$ asam klorida pekat dan $2 \mathrm{ml}$ amil alkohol, dikocok dan dibiarkan memisah. Flavonoid positif jika terjadi warna merah, kuning, jingga pada lapisan amil alkohol (Farnsworth, 1966).

\section{d. Pemeriksaan tanin}

Sebanyak $0,5 \mathrm{~g}$ sampel disari dengan $10 \mathrm{ml}$ air suling, disaring lalu filtratnya diencerkan dengan air suling sampai tidak berwarna. Filtrat yang diperoleh, diambil $2 \mathrm{ml}$ larutan lalu ditambahkan 1 sampai 2 tetes pereaksi besi (III) klorida. Terbentuknya warna biru atau hijau kehitaman menunjukkan adanya tanin (Harborne, 1966).

\section{e. Pemeriksaan glikosida}

Sebanyak $10 \mathrm{~g}$ sampel simplisia ditambahkan $15 \mathrm{ml}$ asam klorida $10 \%$ dipanaskan selama 10 menit, didinginkan dan disaring. Filtrat disaring tiga kali, tiap kali dengan eter. Lapisan asam klorida diambil. Pada lapisan asam klorida, ditambahlan natrium sulfat anhidrat, disaring dan diuapkan. Pada residu, ditambahkan $2 \mathrm{ml}$ aquadest, 8 tetes larutan pereaksi Mollisch, kemudian hati-hati ditambahkan $2 \mathrm{ml}$ asam sulfat P. Hasil positif dilihat dari terbentuknya cincin berwarna ungu pada batas cakram (Ditjen POM, 1995)

\section{Pembuatan ekstrak etanol daun ciplukan}

Pembuatan ekstrak etanol daun ciplukan (EEDC) dilakukan secara maserasi dengan menggunakan pelarut $80 \%$.Etanol $80 \%$ mempunyai makna dalam 100 gram larutan mengandung 80 gram etanol dan sisa 20 gram adalah pelarut. Etanol 96\% mempunyai konsentrasi yang lebih besar dari pada alkohol $80 \%$. Larutan dengan konsentrasi tnggi biasa disebut dengan larutan pekat dan larutan dengan konsentrasi 
rendah disebut dengan larutan encer. Pada prinsip penegnceran berlaku persamaan $\mathrm{V}_{1 \mathrm{x}}$ $\mathrm{M}_{1}=\mathrm{V}_{2 \times} \mathrm{M}_{2}$.

Keterangan:

$\mathrm{V}_{1}=$ Volume larutan pekat yang akan digunakan

$\mathrm{M}_{1}=$ Konsentrasi larutan pekat yang akan diencerkan

$\mathrm{V}_{1}=$ Volume larutan encer yang dibuat $\left(\mathrm{V}_{2}\right.$ adalah $\mathrm{V}_{1}+\mathrm{V}$ air yang ditambah $)$

$\mathrm{M}_{2}=$ konsentrasi larutan encer yang dibuat

Apabila dimasukkan dalam persamaan:

$\mathrm{V}_{1} \times \mathrm{M}_{1}=\mathrm{V}_{2} \times \mathrm{M}_{2}$

$\mathrm{V}_{1} \times 96 \%=1000 \mathrm{~mL} \times 80 \%$

$\mathrm{V}_{1} \quad=(1000 \mathrm{~mL} \times 80 \%): 96 \%$

$\mathrm{V}_{1} \quad=834 \mathrm{~mL}$

Jadi prosedur pembuatan etanol $80 \%$ sebanyak 1 liter adalah dengan mengambil $834 \mathrm{~mL}$ etanol 96\% dicukup dengan aquadest hingga diperoleh volumenya $1.000 \mathrm{~mL}$ (air yang ditambah sebanyak $166 \mathrm{~mL}$ ).Simplisia daun ciplukan (Physallis minima L) diekstraksi dengan cara merendam simplisia daun ciplukan didalam wadah tertutup kemudian ditambahkan pelarut etanol $80 \%$ hingga terendam, lalu lakukan pengocokan sesering mungkin selama 1 minggu, kemudian keluarkan dari botol dan lakukan penyaringan menggunakan kertas saring. Setelah disaring lakukan penguapan dengan Rotary evaporator sehingga diperoleh ekstrak kental (Ditjen POM, 1995).

\section{Persiapan pengujian efek antidiare EEDC}

Persiapan pengujian efek antidiare meliputi penyiapan hewan percobaan, penyiapan bahan uji, bahan kontrol positif, suspensi EEDC sebagai bahan uji, minyak jarak sebagai penginduksi diare, marker dan pengujian efek antidiare.

\section{a. Penyiapan hewan percobaan}

Hewan yang digunakan adalah mencit jantan dengan berat $20-30$ g sebanyak 24 ekor, dibagi dalam 6 kelompok, setiap kelompok terdiri dari 4 ekor mencit. Sebelum digunakan mencit dipelihara selama 2 minggu dengan tujuan untuk menyeragamkan makanan dan hidupnya dengan kondisi yang serba sama sehingga dianggap memenuhi syarat untuk penelitian.

\section{b. Penyiapan bahan}

Bahan yang digunakan meliputi suspensi Na-CMC sebagai kontrol negatif, suspensi Loperamid Hcl sebagai kontrol positif, suspensi EEDC sebagai bahan uji, minyak jarak sebagai penginduksi diare dan dan tinta cina sebagai marker.

\section{c. Pembuatan suspensi Na-CMC 0,5\% (b/v)}

Sebanyak $500 \mathrm{mg}$ Na-CMC ditaburkan kedalam lumpang yang berisi air suling panas. Didiamkan selama 15 menit lalu digerus hingga diperoleh massa yang transparan, digerus sampai homogen. Diencerkan dengan air suling, dihomogenkan dan dimasukkan ke labu tentukur, dicukupkan volumenya dengan air suling hingga $100 \mathrm{ml}$ (Anief M, 1995).

\section{d. Pembuatan suspensi Loperamid $0,0052 \%$}

Satu tablet Lodia mengandung $2 \mathrm{mg}$ loperamid HCL. Sebanyak 20 tablet ditimbang, digerus halus dalam lumpang, kemudian timbang serbuk setara 0,52 $\mathrm{mg}$ loperamid HCL. Serbuk yang ditimbang dimasukkan kedalam lumpang kemudian ditambah suspensi Na-CMC $0,5 \%$ sedikit demi sedikit sambil digerus homogen, kemudian diencerkan hingga $10 \mathrm{ml}$ (Anief M, 1995).

e. Pembuatan suspensi EEDC konsentrasi $0,5 \%, 1 \%, 2 \%$, dan $4 \%$.

Suspensi EEDC dibuat dalam 4 variasi konsentrasi yaitu $0,5 \%, 1 \%, 2 \%$ dan $4 \%$. Sebanyak 50, 100, 200, $400 \mathrm{mg}$ ekstrak etanol daun ciplukan ditimbang, kemudian dimasukkan kedalam lumpang dan ditambahkan suspensi $\mathrm{Na}-\mathrm{CMC} 0,5 \%$ sedikit demi sedikit sambil digerus hingga homogen. Suspensi kemudian dimasukkan ke dalam labu tentukur dan dicukupkan volumenya sampai $10 \mathrm{ml}$ (Anief M, 1995). 


\section{Pengujian aktivitas antidiare EEDC}

Dosis EEDC yang digunakan dalam pengujian ini adalah 50,100, 200, dan 400 $\mathrm{mg} / \mathrm{kg}$ bb. Pengujian yang dilakukan meliputi uji aktivitas antidiare EEDCpada mencit jantan yang diinduksi oleh minyak jarak dan uji aktivitas antimotilitas dengan metode transit intestinal.

a. Uji aktivitas antidiare ekstrak etanol daun ciplukan pada mencit jantan yang diinduksi dengan minyak jarak

Pelaksanaa percobaan ini menggunakan 24 ekor menict jantan yang dibagi secara acak kedalam 6 kelompok perlakuan. Sebelum percobaan dimulai, mencit dipuasakan selama 18 jam tetapi tetap diberi minum. Kelompok I yaitu kelompok kontrol negatif diberi suspensi Na-CMC $0,5 \%$ dosis $50 \mathrm{mg} / \mathrm{kg}$ bb secara oral, kelompok II-V diberi EEDC dengan dosis 50, 100, 200 dan $400 \mathrm{mg} / \mathrm{kg}$ bb secara oral sedangkan kelompok VI yaitu kelompok pembanding diberi loperamid dosis $0,52 \mathrm{mg} / \mathrm{kg}$ bb secara oral (Adnyana et.al., 2004).

Satu jam setelah perlakuan, semua mencit diberikan minyak jarak sebanyak 0,5 $\mathrm{ml}$ untuk menginduksi diare. Mencit diletakkan ke dalam kandang plastik dengan alas kertas saring yang sebelumnya telah ditimbang dan diamati setiap 30 menit selama 5 jam setelah pemberian minyak jarak. Parameter yang diamtai meliputi onset diare, frekuensi diare, terjadinya diare, konsistensi feses dan berat feses serta durasi diare (Adnyana et.al., 2004).

\section{b. Uji aktivitas antimotilitas EEDC dengan metode transit intestinal}

Pelaksanaan percobaan ini menggunakan 24 ekor mencit yang dibagi secara acak kedalam 6 kelompok perlakuan, Sebelum percobaan dimulai, mencit dipuasakan selama 18 jam tetapi tetap diberi minum. Kelompok I yaitu kelompok kontrol negatif diberi suspensi Na-CMC $0,5 \%$ dosis $50 \mathrm{mg} / \mathrm{kg}$ bb secara oral, kelompok II-V diberi EEDC dengan dosis 50, 100, 200 dan $400 \mathrm{mg} / \mathrm{kg}$ bb secara oral sedangkan kelompok VI yaitu kelompok pembanding diberi loperamid dosis $0,52 \mathrm{mg} / \mathrm{kg}$ bb secara oral (Chitme, et al., 2004).

Satu jam setelah perlakuan, semua mencit diberikan minyak jarak sebanyak 0,5 $\mathrm{ml}$ minyak jarak. Setelah 1 jam pemberian minyak jarak, diberikan tinta cina sebanyak $0,1 \mathrm{ml} / 10$ gram mencit secara oral sesuai dengan penelitian yang dilakukan Khori Yusnita 2018. Setelah 1 jam pemberian tinta cina semua hewan dikorbankan dengan cara dislokasi tukang leher. Hewan dibedah dan usunya dikeluarkan secara hati-hati (Chitme, et al., 2004).

Diukur panjang usu yang dilalui marker tinta cina mulai dari pylorus dan katup ileosekal setiap hewan. Kemudian dari masing-masing hewan dihitung persen lintasan yang dilalui oleh marker tinta cina terhadap panjang usus seluruhnya (Chitme, et al., 2004).

\section{Analisis Data}

Nilai rasio kemudian dirata-ratakan masing-masing kelompok dan nilai dari masing-masing kelompok tersebut dibandingkan dengan kelompok lainnya. Data hasil pengamatan dianalisis secara statistik dengan metode ANOVA (analisis of variasi). Analisis statistik ini menggunakan program SPSS (Statistikal Product and Service Solution) versi 18.0.

\section{Hasil dan Pembahasan \\ Pemeriksaan Bahan Tumbuhan}

a. Identifikasi bahan tumbuhan

Hasil identifikasi dari daun ciplukan sudah pernah dilakukan oleh saudari Evi Depiana Gultom di Herbarium Medanense (MEDA) Fakultas Matematika dan Ilmu 
Pengetahuan Alam (MIPA) Universitas Sumatera Utara dimana daun ciplukan yang digunakan peneliti sama dengan peneliti sebelumnya yaitu daun ciplukan (Physallis minima $\mathrm{L}$ ) famili Solanaceae.

\section{b. Hasil karakterisasi simplisia}

Penetapan hasil karakteristik dari serbuk simplisia daun ciplukan dapat diihat pada tabel 1 .

Tabel 1. Hasil karakteristik dari serbuk simplisia daun ciplukan

\begin{tabular}{clcc}
\hline No & $\begin{array}{c}\text { Karakteristik Serbuk } \\
\text { Simplisia }\end{array}$ & Kadar & $\begin{array}{c}\text { Persyaratan MMI (Physallis } \\
\text { minima L) }\end{array}$ \\
\hline 1 & Kadar air & $5,22 \%$ & - \\
& & $8,82 \%$ & Tidak kurang dari $5 \%$ \\
2 & Kadar sari larut dalam air & $3,72 \%$ & Tidak kurang dari $2 \%$ \\
3 & $\begin{array}{l}\text { Kadar sari larut dalam } \\
\text { etanol }\end{array}$ & $6,10 \%$ & Tidak lebih dari $16 \%$ \\
4 & Kadar abu total & Tidak lebih dari $0,5 \%$ \\
5 & $\begin{array}{l}\text { Kadar abu tidak larut } \\
\text { asam }\end{array}$ & $4,64 \%$ & \\
\hline
\end{tabular}

Kadar air simplisia yang diperoleh 5,22\%. Penetapan kadar sari dilakukan menggunakan dua pelarut, yaitu air dan etanol. Penetapan kadar sari larut air adalah untuk mengetahui kadar senyawa kimia bersifat polar yang terkandung di dalam simplisia, sedangkan kadar sari larut dalam etanol dilakukan untuk mengetahui kadar senyawa larut dalam etanol, baik senyawa polar maupun non polar (Natalia, 2014).

Penetapan kadar sari dalam air dilakukan untuk mengetahui jumlah zat yang tersari dalam pelarut air seperti glikosida, gula, gom protein, enzim, zat warna dan asamasam organik dimana kadar air yang diperoleh sebesar $8,82 \%$. Penetapan kadar sari yang larut dalam etanol dilakukan untuk mengetahui jumlah zat yang tersari dalam pelarut etanol seperti glikosida, antrakuinon, steroid, flavonoid, klorofil, saponin, tanin dan yang larut dalam sedikit yaitu lemak. Kadar sari larut dalam etanol yang diperoleh 3,72\%.

Penetapan kadar abu total bertujuan untuk mengetahui kadar senyawa-senyawa anorganik seperti oksida logam $\mathrm{Mg}, \mathrm{Ca}, \mathrm{Pb}$, dan $\mathrm{Zn}$. Penetapan kadar abu tidak larut dalam asam dilakukan untuk mengetahui kadar senyawa yang tidak larut dalam asam seperti silika. Hasil yang didapat untuk kadar abu total adalah kadar abu tidak larut dalama asam adalah sebesar $6,10 \%$ dan $4,64 \%$.

c. Hasil skrinning fitokimia serbuk simplisia dan ekstrak

Hasil skrinning fitokimia serbuk simplisia dan ekstrak etanol daun ciplukan menunjukkan hasil yang sama yang dapat dilihat pada Tabel 4.2.

Tabel 2. Hasil Skrinning fitokimia serbuk simplisia dan EEDC

\begin{tabular}{llcc}
\hline No & \multicolumn{1}{c}{ Senyawa metabolit sekunder } & Simplisia & Ekstrak \\
\hline 1 & Alkaloid & + & + \\
2 & Flavonoid & + & + \\
3 & Glikosida & + & + \\
4 & Tanin & + & + \\
5 & Saponin & + & + \\
\hline
\end{tabular}

Keterangan : $(+)$ : mengandung golongan senyawa metabolit sekunder

Berdasarkan hasil skrinning fitokimia serbuk simplisia dan ekstrak etanol daun ciplukan yang ditunjukkan tabel bahwa serbuk simplisia dan ekstrak etanol daun ciplukan mengandung alkaloid, flavonoid, glikosida, tanin dan saponin. Hasil yang didapatkan 
sesuai dengan penelitian yang telah dilakukan bahwa daun ciplukan mengandung saponin, tanin, flavonoid, alkaloid, glikosida ( Nita fajaryanti et.al., 2018). 


\section{Hasil pengujian efek antidiare}

Sebelum dilakukan pengujian efek antidiare, hewan terlebih dahulu diaklimitasi terhadap lingkungan percobaan. Dosis EEDC yang digunakan dalam pengujian ini adalah $50 \mathrm{mg} / \mathrm{kgBB}, 100 \mathrm{mg} / \mathrm{kgBB}, 200 \mathrm{mg} / \mathrm{kgBB}, 400 \mathrm{mg} / \mathrm{kgBB}$.

a. Hasil uji efek antidiare EEDC pada mencit jantan yang diinduksi oleh minyak jarak

Sebelum dilakukan percobaan, mencit dipuasakan selama 18 jam tetapi tetap diberi minum dengan tujuan pengosongan lambung sehingga mengurangi gangguan absorbsi. Pengujian dilakukan dengan mengelompokkan 24 mencit menjadi 6 kelompok secara acak. Kelompok I yaitu kontrol negatif diberi suspensi Na-CMC 0,5\% dosis 50 $\mathrm{mg} / \mathrm{kgBB}$. Kelompok II-IV yaitu merupakan kelompok bahan uji diberi EEDC dosis 50 $\mathrm{mg} / \mathrm{kgBB}, 100 \mathrm{mg} / \mathrm{kgBB}, 200 \mathrm{mg} / \mathrm{kgBB}, 400 \mathrm{mg} / \mathrm{kgBB}$, sedangkan kontrol positif diberi suspensi Lodia dengan dosis $0,52 \mathrm{mg} / \mathrm{kgBB}$. Semua perlakuan diberikan secara oral. Satu jam setelah perlakuan, 30 menit selama 5 jam setelah pemberian minyak jarak. Respon yang diamati meliputi onset diare (Waktu awal terjadinya diare). Frekuensi diare, konsistensi dan berat feses serta durasi diare (lama terjadinya diare).

\section{1). Waktu awal (Onset) diare}

Waktu awal terjadinya diare (onset diare) ditentukan dengan melihat waktu (menit) pertama hewan uji mengalami diare setelah pemberian minyak jarak. Hasil pengamatan waktu awal diare dapat dilihat pada Tabel 3 dan Gambar 1.

Tabel 3. Hasil analisis waktu awal tejadinya diare mencit jantan yang diinduksi dengan minyak jarak dan diberi suspensi EEDC.

\begin{tabular}{lll}
\hline No. & \multicolumn{1}{c}{ Perlakuan } & Waktu (ment) \pm SEM \\
\hline 1 & Suspensi CMC-Na 0,5\% & $79 \pm 3,89^{*}$ \\
2 & EEDC dosis $50 \mathrm{mg} / \mathrm{kgbb}$ & $102,3 \pm 4,40^{\#}$ \\
3 & EEDC dosis $100 \mathrm{mg} / \mathrm{kgbb}$ & $121,2 \pm 3,09^{\# *}$ \\
4 & EEDC dosis $200 \mathrm{mg} / \mathrm{kgbb}$ & $123 \pm 2,64^{* \#}$ \\
5 & Suspensi Lodia $0,52 \mathrm{mg} / \mathrm{kg} \mathrm{bb}$ & $132,6 \pm 1,31^{\#}$ \\
6 & EEDC dosis $400 \mathrm{mg} / \mathrm{kg} \mathrm{bb}$ & $200 \pm 1,43^{\#^{*}}$ \\
\hline
\end{tabular}

Keterangan : (*) Berbeda signifikan dengan kelompok suspensi lopamid 0,52

$\mathrm{mg} / \mathrm{kgbb}(\mathrm{p}>0,05)$; (\#) Berbeda signifikan dengan kelompok kontrol suspensi NaCMC 0,5\% ( $>0,05)$; (a) Tidak berbeda signifikan dengan kelompok suspensi lodia $0,52 \mathrm{mg} / \mathrm{kgbb}(\mathrm{p}>0,05)$; jumlah mencit jantan $\mathrm{n}=4$, menggunakan uji One Way ANOVA; SEM : Standart Error of mean.

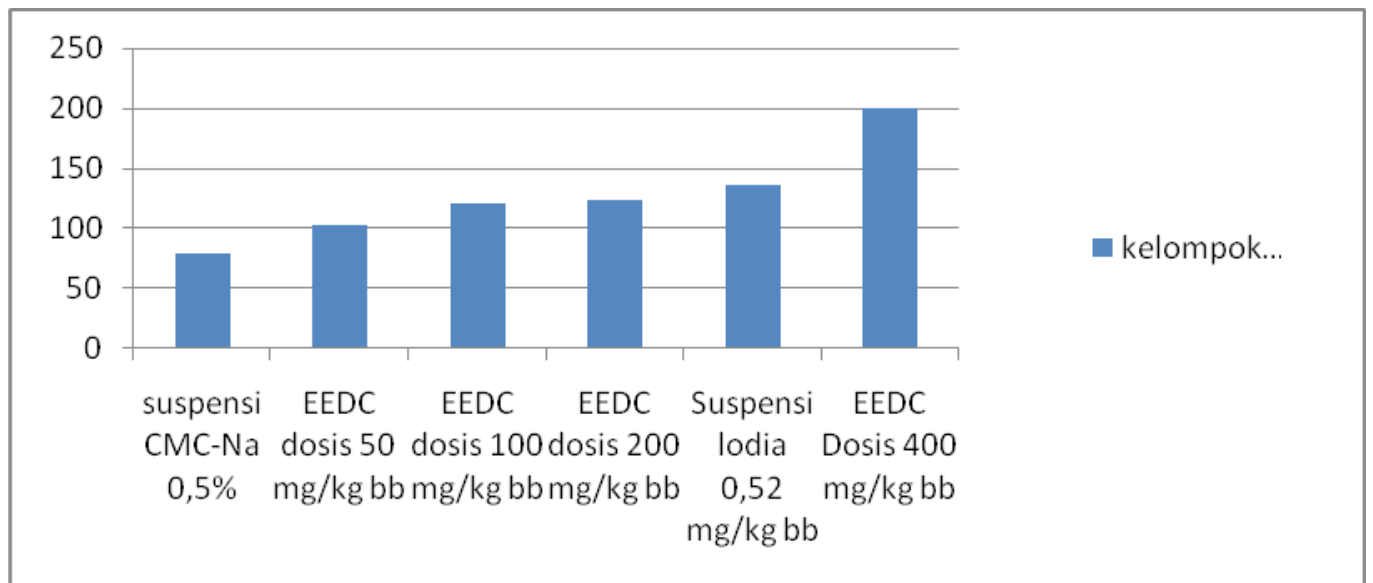

Gambar 1. Grafik rata-rata onset diare mencit jantan yang diinduksi dengan minyak jarak dan diberi perlakuan EEDC 50,100,200,400 mg/kgbb. 
Berdasarkan hasil analisis onset diare yang ditunjukkan pada tabel 3 dan grafik rata-rata onset diare pada gambar 1 dapat dilihat adanya perubahan rata-rata waktu (menit) pertama hewan mengalami diare pada setiap kelompok perlakuan. Kelompok yang hanya diberi suspensi Na-CMC $0,5 \%$ menunjukkan rata-rata awal diare yang paling cepat dibandingkan kelompok lain yaitu pada menit ke $79 \pm 3,89$ setelah diinduksi minyak jarak. Pada kelompok hewan yang diberi EEDC dosis $50 \mathrm{mg} / \mathrm{kgbb}$ diperoleh ratarata waktu awal diare pada menit ke 102,3 \pm 4,40. Pada kelompok EEDC dosis 100, 200 diperoleh waktu awal diare yang semakin lma seiring dengan peningktan dosis yaitu pada mencit ke 121,2 $\pm 3,09 ; 123 \pm 2,64 ; 132,6 \pm 1,31$. Kelompok EEDC dosis $400 \mathrm{mg} / \mathrm{kgbb}$ mengalami awal diare yang paling lama yaitu pada menit ke $200 \pm 1,43$ setelah diinduksi minyak jarak.

Berdasarkan uji statistik ANOVA ( $>00,05)$ dilanjutkan uji beda rata-rata Tukey $H S D$ diperoleh bahwa kelompok suspensi lopamid 0,52 mg/kgbb, EEDC $50 \mathrm{mg} / \mathrm{kg} \mathrm{bb}$, $100 \mathrm{mg} / \mathrm{kg} \mathrm{bb}, 200 \mathrm{mg} / \mathrm{kg}$ bb berbeda signifikan dengan kelompok kontrol Na-CMC $0,5 \%$ dengan nilai $(\mathrm{p}<0,05)$. Kelompok EEDC dosis $50 \mathrm{mg} / \mathrm{kg} \mathrm{bb}$, menunjukkan perbedaan yang signitifikan dengan kelompok kontrol suspensi lopamid 0,52 $\mathrm{mg} / \mathrm{kg}$ bb $(\mathrm{p}<0,05)$ Kelompok EEDCdosis $400 \mathrm{mg} / \mathrm{kg} \mathrm{bb}$, menunjukkan perbedaan yang signifikan dengan kelompok kontrol suspensi Na-CMC dan suspensi lodia $0,52 \mathrm{mg} / \mathrm{kg} b \mathrm{~b}(\mathrm{p}<0,05)$.

Kelompok uji dinyatakan memiliki efek antidiare, jika onset diare (waktu awal terjadinya diare) yang diperoleh lebih lama dibandingkan dengan kelompok kontrol suspensi Na-CMC 0,5\% Semakin cepat terjadi diare maka efek antidiare semakin lemah.

\section{2). Frekuensi diare}

Frekuensi diare ditentukan dengan cara menghitung berapa kali hewan mengalami diare setelah diinduksi minyak jarak selama 5 jam setiap 30 menit. Hasil pengamatan frekuensi diare dari setiap kelompok perlakuan dapat dilihat pada Tabel 4 dan Gambar 2.

Tabel 4. Hasil analisis data frekuensi diare mencit jantan yang diinduksi dengan minyak jarak dan diberi suspensi EEDC

\begin{tabular}{lll}
\hline No & Perlakuan & Frekuensi (kali) \pm SEM \\
\hline 1 & Suspensi CMC-Na 0,5\% & $14,50 \pm 1,19^{*}$ \\
2 & EEDC dosis $50 \mathrm{mg} / \mathrm{kgbb}$ & $8,50 \pm 0,64^{\#}$ \\
3 & EEDC dosis $100 \mathrm{mg} / \mathrm{kgbb}$ & $6,50 \pm 0,64^{\#}$ \\
4 & EEDC dosis $200 \mathrm{mg} / \mathrm{kgbb}$ & $4,75 \pm 0,47^{\text {\#a }}$ \\
5 & EEDC dosis $400 \mathrm{mg} / \mathrm{kgbb}$ & $2,75 \pm 0,47^{\text {a\# }}$ \\
6 & Suspensi Lodia $0,52 \mathrm{mg} / \mathrm{kgbb}$ & $4,20 \pm 0,37^{\text {a\# }}$ \\
\hline
\end{tabular}

Keterangan : (*) Berbeda signifikan dengan kelompok suspensi lopamid 0,52

$\mathrm{mg} / \mathrm{kgbb}(\mathrm{p}>0,05)$; (\#) Berbeda signifikan dengan kelompok kontrol suspensi NaCMC 0,5\% (p>0,05); (a) Tidak berbeda signifikan dengan kelompok suspensi lodia $0,52 \mathrm{mg} / \mathrm{kgbb}(\mathrm{p}>0,05)$; jumlah mencit jantan $\mathrm{n}=4$, menggunakan uji One Way ANOVA; SEM : Standart Error of mean. 


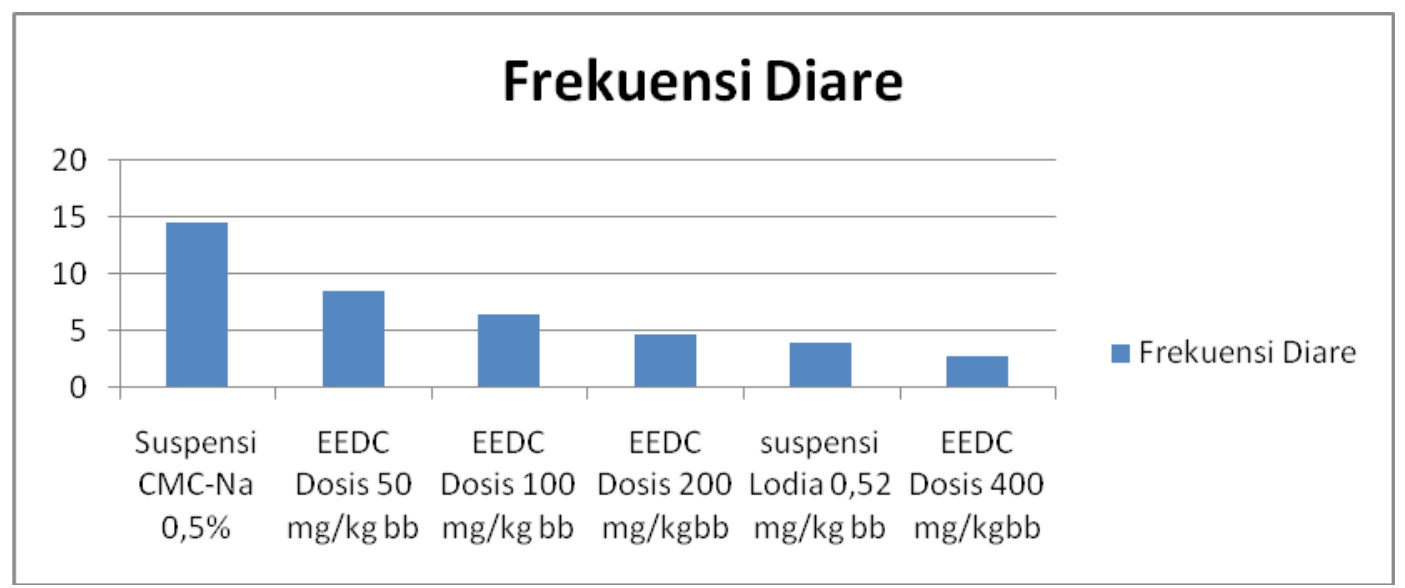

Gambar 2. Grafik rata-rata frekuensi diare mencit jantan yang diinduksi dengan minyak jarak dan diberi perlakuan EEDC 50,100,200,400 mg/kgbb.

Berdasarkan hasil analisis data frekuensi diare yang ditunjukkan pada Tabel 4 dan grafik rata-rata frekuensi diare yang ditunjukkan pada Gambar 2 adanya perubahan rata-rata frekuensi diare dari setiap kelompok perlakuan. Kelompok kontrol suspensi NaCMC $0,5 \%$ menunjukkan penurunan rata-rata frekuensi diare yang paling besar yaitu $14,50 \pm 1,19$. Kelompok EEDC dosis 50, 100, 200, 400 menunjukkan penurunan rata-rata pada frekuensi diare seiring dengan bertambahnya dosis. Lodia 0,52 mg/kgbb menunjukkan rata-rata frekuensi diare yang lebih kecil dibandingkan dengan kelompok

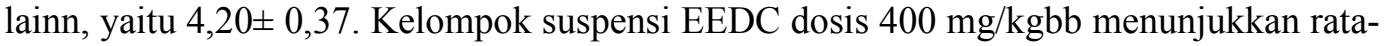
rat frekuensi diare paling kecil dibandingkan kelompok lain, yaitu sebanyak 2,75 $\pm 0,47$ kali.

Berdasarkan uji statistik ANOVA $(\mathrm{P}<0,05)$ dilanjutkan uji rata Tukey HSD diperoleh bahwa kelompok lopapmid0,52 mg/kgbb, EEDC dosis $50 \mathrm{mg} / \mathrm{kgbb}, 100$ $\mathrm{mg} / \mathrm{kgbb}, 200 \mathrm{mg} / \mathrm{kgbb}, 400 \mathrm{mg} / \mathrm{kgbb}$ menunjukkan perbedaan yang signifikan dengan kelompok kontrol Na-CMC $0,5 \%$ dengan nilai $(\mathrm{p}<0,05)$. Kelompok EEDC dosis 50 dan $100 \mathrm{mg} / \mathrm{kgbb}$ berbeda signifikan kelompok Lodia $0,52 \mathrm{mg} / \mathrm{kg}$ bb $(\mathrm{p}>0,05)$. Kelompok EEDC Dosis $200 \mathrm{mg} / \mathrm{kg}$ bb dan $400 \mathrm{mg} / \mathrm{kg}$ bb tidak berbeda signifikan dengan suspensi $0,52 \mathrm{mg} / \mathrm{kg}$ bb ( $\mathrm{p}>0,05)$. Kelompok uji dinyatakan memiliki efek antidiare., jika frekuensi diare yang diperoleh lebih sedikit dibandingkan kelompok kontrol suspensi Na-CMC $0,5 \%$.

\section{c). Konsistensi dan berat Feses}

Konsistensi dan berat feses ditentukan dengan cara menimbang berat feses hewan setiap 30 menit selama 5 jam dan diamati konsistensi fesesnya. Hasil pengamatan konsistensi dan berat fesesdapat dilihat pafa Tabel 5, Tabel 6, Tabel 7 dan Gambar 3.

Tabel 5. Hasil analisis data berat feses padat mencit jantan yang diinduksi dengan minyak jarak dan diberi suspensi EEDC.

\begin{tabular}{lll}
\hline No & Perlakuan & Berat (gram) \pm SEM \\
\hline 1 & Suspensi CMC-Na $0,5 \%$ & $0,31 \pm 0,01^{*}$ \\
2 & EEDC dosis $50 \mathrm{mg} / \mathrm{kg} \mathrm{bb}$ & $0,20 \pm 0,01^{\#}$ \\
3 & EEDC dosis $100 \mathrm{mg} / \mathrm{kgbb}$ & $0,22 \pm 0,01^{\text {\#a }}$ \\
4 & EEDC dosis $200 \mathrm{mg} / \mathrm{kgbb}$ & $0,11 \pm 0,01^{\text {\#a }}$ \\
5 & EEDC dosis $400 \mathrm{mg} / \mathrm{kgbb}$ & $0,07 \pm 0,03^{\# \mathrm{a}}$ \\
6 & Suspensi Lodia $0,52 \mathrm{mg} / \mathrm{kg} \mathrm{bb}$ & $0,13 \pm 0,02^{\#}$ \\
\hline
\end{tabular}

Keterangan : (*) Berbeda signifikan dengan kelompok suspensi lopamid 0,52 
$\mathrm{mg} / \mathrm{kgbb}(\mathrm{p}>0,05)$; (\#) Berbeda signifikan dengan kelompok kontrol suspensi NaCMC 0,5\% ( $>0,05)$; (a) Tidak berbeda signifikan dengan kelompok suspensi lodia $0,52 \mathrm{mg} / \mathrm{kgbb}(\mathrm{p}>0,05)$; jumlah mencit jantan $\mathrm{n}=4$, menggunakan uji One Way ANOVA; SEM : Standart Error of mean.

Berdasarkan uji statistik ANOVA $(\mathrm{p}<0,05)$ dilanjutkan dengan uji beda rata-rata Tukey HSDdiperoleh bahwa kelompok suspensi lopamid $0,52 \mathrm{mg} / \mathrm{kg}$ bb tidak berbeda signifikan $(\mathrm{p}<0,05)$ dengan kelompok EEDC dosis $400 \mathrm{mg} / \mathrm{kg} \mathrm{bb}, 200 \mathrm{mg} / \mathrm{kg} \mathrm{bb}$, $100 \mathrm{mg} / \mathrm{kg}$ bb dan $50 \mathrm{mg} / \mathrm{kg}$ bb. Pada kelompok EEDC dosis 50, 100, 200, dan $400 \mathrm{mg} / \mathrm{kg}$ $\mathrm{bb}$ dan kelompok suspensi Lodia $0,52 \mathrm{mg} / \mathrm{kg}$ bb berbeda signifikan $(\mathrm{p}<0,05)$ dengan kelompok suspensi CMC-Na 0,5\%.

Hasil statistik ini diketahui bahwa EEDC dosis 50, 100, 200, dan 400 menunjukkan profil konsistensi feses padat yang lebih baik dibandingkan kelompok kontrol negatif dan memperlihatkan profil yang sebanding dengan kelompok Lodia.

Tabel 6. Hasil analisis data berat feses berair mencit jantan yang diinduksi dengan minyak jarak dan diberi suspensi EEDC.

\begin{tabular}{lll}
\hline No & \multicolumn{1}{c}{ Perlakuan } & \multicolumn{1}{c}{ Berat (gram) \pm SEM } \\
\hline 1 & Suspensi CMC-Na 0,5\% & $0,51 \pm 0,05^{*}$ \\
2 & EEDC dosis $50 \mathrm{mg} / \mathrm{kg} \mathrm{bb}$ & $0,25 \pm 0,02^{\#}$ \\
3 & EEDC dosis $100 \mathrm{mg} / \mathrm{kgbb}$ & $0,24 \pm 0,01^{\text {a\# }}$ \\
4 & EEDC dosis $200 \mathrm{mg} / \mathrm{kgbb}$ & $0,15 \pm 0,02^{\# \mathrm{a}}$ \\
5 & EEDC dosis $400 \mathrm{mg} / \mathrm{kgbb}$ & $0,13 \pm 0,02^{\# \mathrm{a}}$ \\
6 & Suspensi Lodia $0,52 \mathrm{mg} / \mathrm{kg}$ bb & $0,13 \pm 0,01^{\#}$ \\
\hline
\end{tabular}

Keterangan : (*) Berbeda signifikan dengan kelompok suspensi lopamid 0,52

$\mathrm{mg} / \mathrm{kgbb}(\mathrm{p}>0,05)$; (\#) Berbeda signifikan dengan kelompok kontrol suspensi NaCMC 0,5\% (p>0,05); (a) Tidak berbeda signifikan dengan kelompok suspensi lodia $0,52 \mathrm{mg} / \mathrm{kgbb}(\mathrm{p}>0,05)$; jumlah mencit jantan $\mathrm{n}=4$, menggunakan uji One Way ANOVA; SEM : Standart Error of mean.

Berdasarkan uji statistik ANOVA $(\mathrm{p}<0,05)$ dilanjutkan dengan uji (beda rata-rata Tukey HSDdiperoleh bahwa kelompok CMC-Na berbeda signifikan $(\mathrm{p}<0,05)$ dengan kelompok suspensi lopamid 0,52 mg/kg bb dan kelompok EEDC dosis 50, 100, 200 dan $400 \mathrm{mg} / \mathrm{kg} \mathrm{bb}$. Kelompok EEDC dosis $50 \mathrm{mg} / \mathrm{kg}$ bb bereda signifikan dengan Lodia 0,52 $\mathrm{g} / \mathrm{kg} \mathrm{bb}(\mathrm{p}<0,05)$. Pada kelompok EEDCdosis 100, 200, dan $400 \mathrm{mg} / \mathrm{kg}$ bb tidak berbeda signifikan tidak berbeda signifikan dengan kelompok suspensi Lodia $0,52 \mathrm{mg} / \mathrm{kg}$ bb $(\mathrm{p}<0,05)$.

Tabel 7. Hasil analisis data berat feses lembek mencit jantan yang diinduksi dengan minyak jarak dan diberi suspensi EEDC.

\begin{tabular}{lll}
\hline No & \multicolumn{1}{c}{ Perlakuan } & Berat (gram) \pm SEM \\
\hline 1 & Suspensi CMC-Na 0,5\% & $1,23 \pm 0,05^{*}$ \\
2 & EEDC dosis $50 \mathrm{mg} / \mathrm{kg} \mathrm{bb}$ & $0,94 \pm 0,14^{\# *}$ \\
3 & EEDC dosis $100 \mathrm{mg} / \mathrm{kgbb}$ & $0,55 \pm 0,05^{\# \mathrm{a}}$ \\
4 & EEDC dosis 200 mg/kgbb & $0,30 \pm 0,02^{\# \mathrm{a}}$ \\
5 & EEDCdosis 400 mg/kgbb & $0,23 \pm 0,03^{\# \mathrm{a}}$ \\
6 & Suspensi Lodia 0,52 $\mathrm{mg} / \mathrm{kg} \mathrm{bb}$ & $0,30 \pm 0,02^{\#}$ \\
\hline
\end{tabular}

Keterangan : (*) Berbeda signifikan dengan kelompok suspensi lopamid 0,52

$\mathrm{mg} / \mathrm{kgbb}(\mathrm{p}>0,05) ;(\#)$ Berbeda signifikan dengan kelompok kontrol suspensi NaCMC 0,5\% ( $>0,05)$; (a) Tidak berbeda signifikan dengan kelompok suspensi lodia $0,52 \mathrm{mg} / \mathrm{kgbb}(\mathrm{p}>0,05)$; jumlah mencit jantan $\mathrm{n}=4$, menggunakan uji One Way ANOVA; SEM : Standart Error of mean. 
Berdasarkan uji statistik ANOVA $(\mathrm{p}<0,05)$ dilanjutkan dengan uji beda rata-rata Tukey HSD diperoleh bahwa kelompok suspensi lopamid 0,52 mg/kg bb, EEDC dosis 50, 100, 200 dan $400 \mathrm{mg} / \mathrm{kg}$ bb berbeda signifikan $(\mathrm{p}<0,05)$ dengan kelompok suspensi CMC-Na 0,5\%. Kelompok EEDC dosis $50 \mathrm{mg} / \mathrm{kg}$ bb berbeda signifikan dengan suspensi Lodia $0,52 \mathrm{mg} / \mathrm{kg}$ bb (p<0,05). Pada kelompok EEDC dosis 100, 200 dan $400 \mathrm{mg} / \mathrm{kg} \mathrm{bb}$ tidak berbeda signifikan dengan suspensi lopamid $0,52 \mathrm{mg} / \mathrm{kg} b \mathrm{bb}(\mathrm{p}<0,05)$.

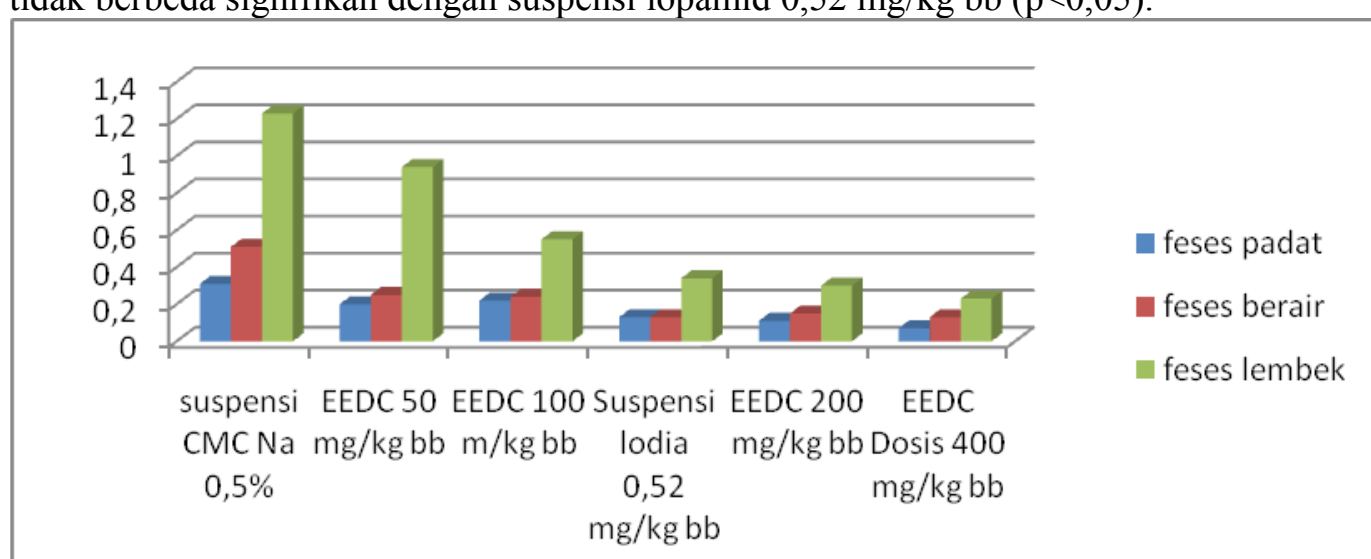

Gambar 3. Grafik rata-rata konsistensi berat feses diare mencit jantan yang diinduksi dengan minyak jarak dan diberi perlakuan EEDC 50,100,200,400 mg/kgbb.

Berdasarkan hasil analisis berat feses mencit yang ditunjukkan oleh Tabel 5, Tabel 6, Tabel 7 dan Gambar 3 menujukkan perbedaan dan berat feses dari setiap kelompok perlakuan. Kelompok kontrol suspensi Na-CMC 0,5\% menunjukkan beratfeses paling besar dibandingkan dengan kelompok perlakuan lainnya, baik feses padat, berair maupun lembek. Hal ini dikarenakan pada kelompok kontrol suspensi Negatif Na-CMC $0,5 \%$ tidak adanya penghambatan minyak jarak untuk menyebabkan diare sehingga gerakan peristaltik dari usus yang tinggi menyebabkan absorbansi air tidak sempurna dan konsistensi feses menjadi lembek. Kelompok EEDC menunjukkan penurunan berat feses seiring dengan bertambah besarnya dosis yang diberikan. Hal ini diduga karena kandungan metabolit sekunder yang terkandung pada daun ciplukan, seperti tanin.

Kelompok uji dinyatakan memiliki efek antidiare jika berat feses yang diperoleh lebih kecil dibandingkan kelompok kontrol suspensi Na-CMC 0,5\%. Semakin berat feses yang diperoleh maka efek antidiare akan semakin lemah.

\section{d). Durasi diare}

Lama terjadinya diare (durasi diare) ditentukan dengan mencatat waktu hewan pertama kali diare dengan konsistensi berair atau lembek sampai kembali membentuk feses dengan konsistensi padat. Hasil pengamatan durasi diare dapat dilihat pada Tabel 8 dan Gambar 4.

Tabel 8. Hasil analisis data durasi mencit jantan yang diinduksi dengan minyak jarak dan diberi suspensi EEDC.

\begin{tabular}{lll}
\hline No & \multicolumn{1}{c}{ Perlakuan } & \multicolumn{1}{c}{ Berat (gram) \pm SEM } \\
\hline 1 & Suspensi CMC-Na 0,5\% & $196,70 \pm 4,81^{*}$ \\
2 & EEDC dosis $50 \mathrm{mg} / \mathrm{kg} \mathrm{bb}$ & $155,00 \pm 5,75^{* \#}$ \\
3 & EEDC dosis $100 \mathrm{mg} / \mathrm{kgbb}$ & $142,00 \pm 1,68^{\# *}$ \\
4 & EEDC dosis $200 \mathrm{mg} / \mathrm{kgbb}$ & $112,25 \pm 11,75^{\# \mathrm{a}}$ \\
5 & EEDC dosis $400 \mathrm{mg} / \mathrm{kgbb}$ & $64,25 \pm 4,76^{\# *}$ \\
6 & Suspensi Lodia $0,52 \mathrm{mg} / \mathrm{kg} \mathrm{bb}$ & $92,80 \pm 6,15^{\#}$ \\
\hline
\end{tabular}

Keterangan : (*) Berbeda signifikan dengan kelompok suspensi lopamid 0,52

$\mathrm{mg} / \mathrm{kgbb}(\mathrm{p}>0,05)$; (\#) Berbeda signifikan dengan kelompok kontrol suspensi NaCMC 0,5\% ( $>0,05)$; (a) Tidak berbeda signifikan dengan kelompok suspensi 
lodia $0,52 \mathrm{mg} / \mathrm{kgbb}(\mathrm{p}>0,05)$; jumlah mencit jantan $\mathrm{n}=4$, menggunakan uji One Way ANOVA; SEM : Standart Error of mean.

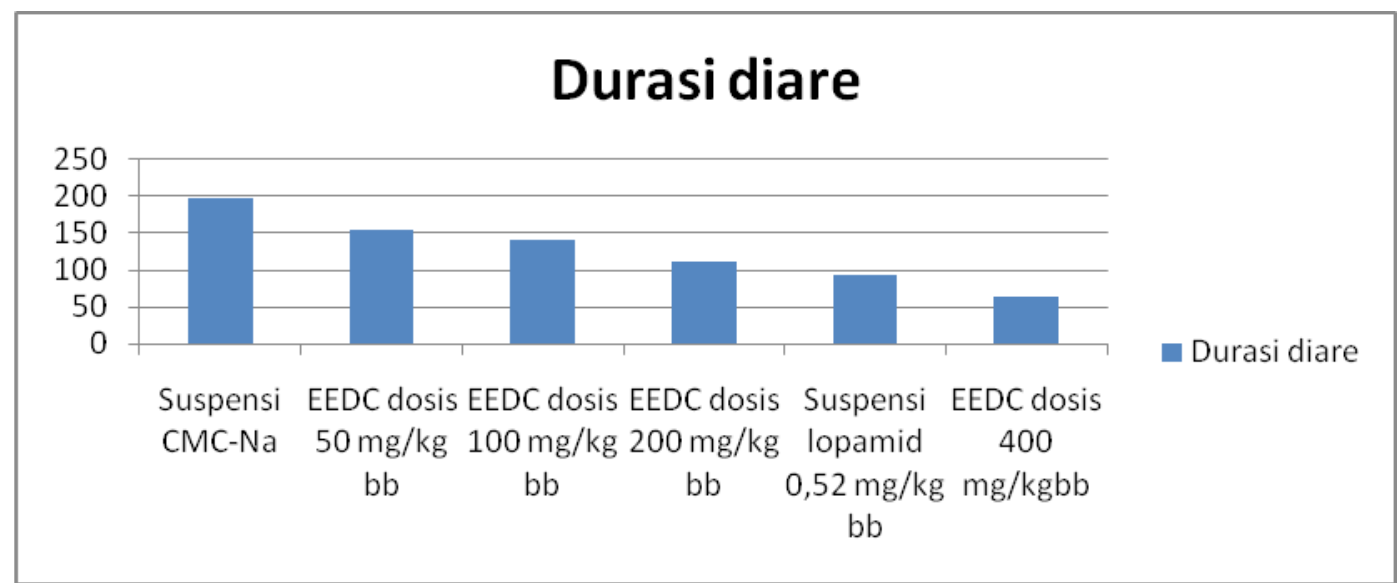

Gambar 4. Grafik rata-rata durasi diare mencit jantan yang diinduksi dengan minyak jarak dan diberi perlakuan EEDC 50,100,200,400 mg/kgbb.

Berdasarkan hasil analisa yang ditunjukkan Tabel 8 dan Gambar 4 perubahan durasi diare antara setiap kelompok perlakuan. Kelompok suspensi Na-CMC 0,5\% menunjukkan duarsi diare paling lama dibandingkan dibandingkan dengan kelompok lain yaitu $197 \pm$ 4,81 menit.

Kelompok EEDC menunjukkan perubahan durasi diare seiring dengan peningkatan dosis. Kelompok suspensi EEDC $400 \mathrm{mg} / \mathrm{kg}$ bb menunjukkan durasi diare tersingkat dibandingkan dengan kelompok lain yaitu 64,25 $\pm 4,76$ menit. Berdasarkan uji statistik ANOVA dilanjutkan dengan uji beda rata-rata Tukey HSDdiperoleh hasil analisis seperti yang ditunjukkan pada Tabel 4.8. Kelompok EEDC dosis 50, 100, 200, $400 \mathrm{mg} / \mathrm{kg}$ $\mathrm{bb}$ dan kelompok suspensi Lodia $0,52 \mathrm{mg} / \mathrm{kg}$ bb bereda siginifikan $(\mathrm{p}<0,05)$ dengan kelompok suspensi CMC-Na 0,5\%. Kelompok EEDC dosis $50 \mathrm{mg} / \mathrm{kg}$ bb tidak berbeda signifikan $(\mathrm{p}<0,05)$ dengan kelompok EEDC dosis $100 \mathrm{mg} / \mathrm{kg}$ bb tetapi berbeda signifikan $(\mathrm{p}<0,05)$ dengan kelompok suspensi Lodia $0,52 \mathrm{mg} / \mathrm{kg}$ bb. Kelompok EEDC dosis $200 \mathrm{mg} / \mathrm{kgb}$ bb tidak berbeda signifikan $(\mathrm{p}<0,05)$ dengan kelompok suspensi 0,52 $\mathrm{mg} / \mathrm{kg}$ bb. Kelompok EEDC dosis $400 \mathrm{mg} / \mathrm{kg}$ bb berbeda signifikan dengan kelompok suspensi Lodia $0,52 \mathrm{mg} / \mathrm{kg}$ bb $(\mathrm{p}<0,05)$.

\section{b. Hasil uji aktivitas antimotilitas EEDC dengan metode transit intestinal}

Sebanyak 24 ekor mencit jantan dipuasakan selama 18 jam dan dibagi dalam 6 kelompok perlakuan. Kelompok I yaitu kontrol negatif diberi suspensi Na-CMC 0,5\% dosis $50 \mathrm{mg} / \mathrm{kg}$ bb. Kelompok II-V yang merupakan kelompok bahan uji diberi ekstrak etabol daun ciplukan dosis 50, 100, 200 dan $400 \mathrm{mg} / \mathrm{kg}$ bb sedangkan kelompok VI adalah kontrol positif diberi suspensi Lodia dengan dosis $0,52 \mathrm{mg} / \mathrm{kg} \mathrm{bb}$. Semua perlakuan diberikan secara oral. Satu jam perlakuan semua mencit diberi $0,5 \mathrm{ml}$ minyak jarak. Setelah 1 jam pemberian minyak jarak, diberikan tintacina sebanyak $0,1 \mathrm{ml}$ secara oral. Setelah satu jam pemberian tinta cina, semua hewan dikorbankan dengan cara dislokasi tulang leher. Hewan dibedah dan ususnya dikeluarkan secara hati-hati. Diukur panjang usus yng lalui marker tinta cina mulai dari pylorus dan katup ileosekal dari masing-masing hewan. 
Tabel 9. Hasil anaslisis data persen lintas marker tinta cina pada mencit jantan yang diinduksi minyak jarak dan dibri suspensi EEDC.

\begin{tabular}{llc}
\hline No & \multicolumn{1}{c}{ Perlakuan } & Persen (\%) \pm SEM \\
\hline 1 & Suspensi CMC-Na 0,5\% & $88,10 \pm 3,23^{*}$ \\
2 & EEDC dosis $50 \mathrm{mg} / \mathrm{kg} \mathrm{bb}$ & $70,22 \pm 2,25^{\#^{*}}$ \\
3 & EEDC dosis $100 \mathrm{mg} / \mathrm{kg} \mathrm{bb}$ & $54,33 \pm 1,69^{\# *}$ \\
4 & EEDC dosis $200 \mathrm{mg} / \mathrm{kg} \mathrm{bb}$ & $61,71 \pm 1,00^{\# *}$ \\
5 & EEDC dosis $400 \mathrm{mg} / \mathrm{kg} \mathrm{bb}$ & $39,97 \pm 2,22^{\# \mathrm{a}}$ \\
6 & Suspensi Lodia $0,52 \mathrm{mg} / \mathrm{kg} \mathrm{bb}$ & $38,74 \pm 1,36^{\#}$ \\
\hline
\end{tabular}

Keterangan : (*) Berbeda signifikan dengan kelompok suspensi lopamid 0,52

$\mathrm{mg} / \mathrm{kgbb}(\mathrm{p}>0,05)$; (\#) Berbeda signifikan dengan kelompok kontrol suspensi NaCMC 0,5\% ( $>0,05)$; (a) Tidak berbeda signifikan dengan kelompok suspensi lodia $0,52 \mathrm{mg} / \mathrm{kgbb}(\mathrm{p}>0,05)$; jumlah mencit jantan $\mathrm{n}=4$, menggunakan uji One Way ANOVA; SEM : Standart Error of mean.

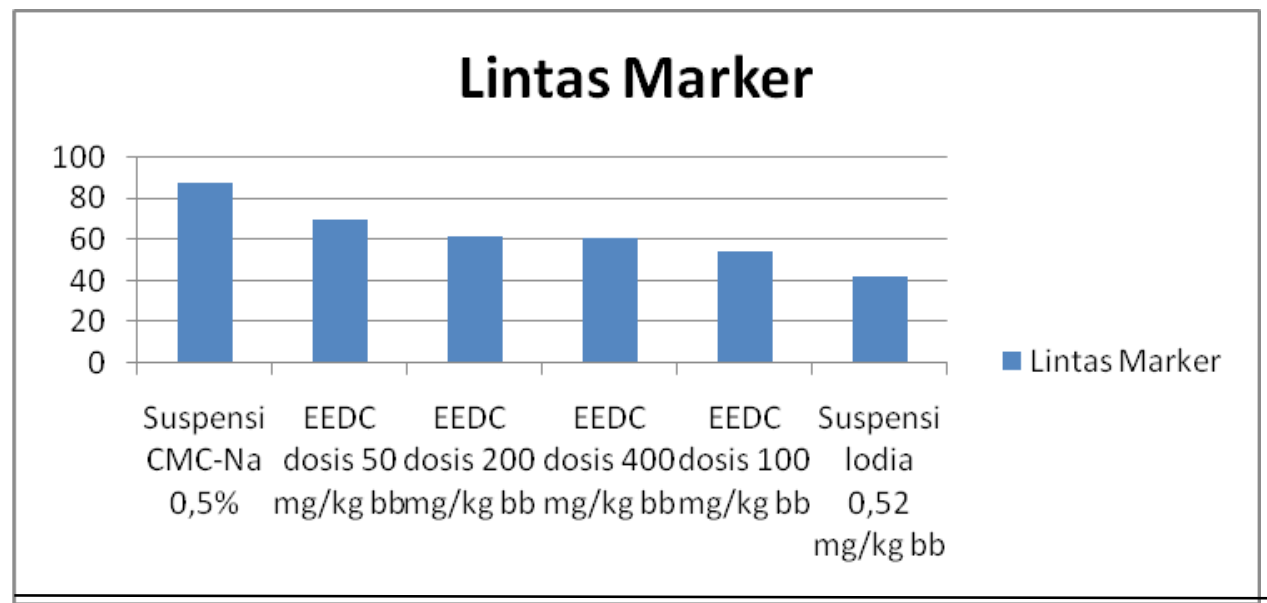

Gambar 5. Grafik rata-rata lintas marker mencit jantan yang diinduksi dengan minyak jarak dan diberi perlakuan EEDC 50,100,200,400 mg/kgbb.

Berdasarkan hasil analisa yang ditunjukkan Tabel 4.9 dan Gambar 4.5 adanya perbedaan persen lintas marker tinta cina dari setiap kelompok perlakuan. Kelompok perlakuan EEDC dosis 50,100, 200 dan $400 \mathrm{mg} / \mathrm{kg}$ bb dan suspensi lopamid 0,52 mg/kg berbeda signifikan dengan kelompok suspensi CMC-Na 0,5\% $(\mathrm{p}<0,05)$. Kelompok EEDC dosis $50,100,200$ dan $400 \mathrm{mg} / \mathrm{kg}$ bb berbeda siginifikan $(\mathrm{p}<0,05)$ dengan kelompok Lodia $0,52 \mathrm{mg} / \mathrm{kg}$. Kelompok EEDC dosis $50 \mathrm{mg} / \mathrm{kg}$ bb berbeda signifikan dengan EEDC dosis $200 \mathrm{mg} / \mathrm{kg}$ bb. Data tersebut dapat disimpulkan bahwa peningkatan dosis EEDC menunjukkan penurunan motilitas usus pada mencit. Pengujian data pada dosis 400 $\mathrm{mg} / \mathrm{kg}$ bb memiliki efek antidiare yang sebanding dengan suspensi Lodia $0,52 \mathrm{mg} / \mathrm{kg}$ bb.

Penelitian ini dilakukan dengan dua metode, yaitu metode transit intestinal metode lintas usus halus dengan tinta cina sebagai marker dan metode defekasi. Metode transit intestinal metode lintas usus ini bertujuan untuk mengevaluasi aktivitas obat anti diare, laksania, ataupun antispasmodik, berdasarkan pengaruhnya pada rasio jarak usus yang ditempuh oleh suatu norit dalam jangka waktu tertentu terhadap panjang usus keseluruhan hewan percobaan (KKIPM, 1993). Penelitian ini menggunakan minyak jarak atau oleum ricini sebagai penginduksi diare. Trigliserida dan asam risinoleat yang terdapat dalam minyak jarak akan mengalami hidrlisis dalam usus halus oleh lipase pankreas menjadi trigliserida dan asam risinoleat (KKIPM, 1993). Asam risinoleat merupakan metabolit aktif dari minya jarak mampu menginduksi diare dengan cara meningkatkan aktivitas peristaltik dimukosa intestinal, sehingga akan mengakibatkan 
perubahan permeabilitas sel mukosa intestinal terhadap cairan dan elektrolit (Ammon et al, 1974).

Daun ciplukan mengandung saponim, tanin, flavonoid, alkaloid (Joko Suryo, 2010). Golongan senyawa yang mempunyai efek antidiare adalah tanin dan Flavonoid. Tanin diketahui mempunyai sifat astringents yang bekerja sebagai penciutan lapisan sel sehingga menghambat jaringan sekresi. Sedangkan Flavonoid diketahui bisa menghambat pelepasan asetilkolin pada saluran cerna (Mustchler 1999 \& Lutterdort, 1989). Golongan senyawa yang diduga mempunyai efek antibakteri adalah alkaloid, tanin, dan flavonoid, dimana alkaloid sebagai anti bakteri mempunyai gugus aromatik yang dapat memempngaruhi DNA akteri sehingga menyebabkan terhambatnya pertumbuhan bakteri, sedangkan pada flavonoid memiliki mekanisme kerja antibakteri diduga karena kemampuannya membentuk kompleks dengan proein ekstraseluler sehingga dapat merusak membran sel bakteri dengan keluarnya senyawa intraseluler, semakin lipofil suatu flavonoid maka kemampuannya merusak membran sel bakteri akan semakin besar (Sukmawati et.al., 2017).

Mekanisme flavonoid menghentikan diare yang diinduksi dengan oleum ricini adalah dengan menghambat motilitas usus sehingga mengurangi sekresi cairan dan elektrolit (Di Carlo, 1993).

\section{Kesimpulan}

Berdasarkan pembahasan hasil penelitian dapat disimpulkan bahwa :

a. $\quad$ EEDC dosis $50 \mathrm{mg} / \mathrm{kg} \mathrm{bb}, 100 \mathrm{mg} / \mathrm{kg} \mathrm{bb}, 200 \mathrm{mg} / \mathrm{kg}$ bb dan $400 \mathrm{mg} / \mathrm{kg}$ bb memiliki efek sebagai antidiare terhadap mencit jantan diinduksi minyak jarak.

b. Dosis efektif EEDC sebagai antidiare adalah $200 \mathrm{mg} / \mathrm{kg}$ bb dan $400 \mathrm{mg} / \mathrm{kg} \mathrm{bb}$ dengan menunjukkan perbedaan signifikan $(p<0,05)$ dari kontrol negatif dan tidak berbeda signifikan dengan kontrol positif .

c. Peningkatan dosis EEDC dari dosis $50 \mathrm{mg} / \mathrm{kg} \mathrm{bb}, 10 \mathrm{mg} / \mathrm{kg} \mathrm{bb}, 200 \mathrm{mg} / \mathrm{kg} b$ dan dosis $400 \mathrm{mg} / \mathrm{kg}$ bb menunjukkan peningkatan efek antidiare.

\section{Referensi}

Adnyana dkk, 2004 ; Yasnita, Khori. 2018. “ Uji Efek Antidiare Ekstrak Etanol Daun Laban (Vitex Quinata Lour.F.N. Williams) Terhadap Mencit Jantan “. Medan : Universitas Sumatera Utara.

Agoes, 2007 ; EM Sutrisna, M. Kes, 2016. "Herbal Medicine : Suatu tinjauan farmakologis". Surakarta : Muhammadiyah University Press.

Agromedia, 2008. "273 Ramuan Tradisional". Jakarta : PT Agromedia Pustaka.

Ahadi, 2003 ; Yasnita, Khori. 2018. " Uji Efek Antidiare Ekstrak Etanol Daun Laban (Vitex Quinata Lour.F.N. Williams) Terhadap Mencit Jantan “. Medan : Universitas Sumatera Utara.

Ajizah, Aulia. 2004. "Sensivitas Salmonella Typhimuriumterhadap ekstrak daun Psidium guajava L. Jurnal Penelitian pendidikan biologi. Vol. 1 : hal. 31-38.

Alkautsari, Luki. 2016. "Uji Aktivitas antibakteri ekstrak daun Ciplukan (Physallis minima Linn.) terhadap pertumbuhan bakteri Salmonella sp".Jurnal Pendidikan biologi. Padang : Sekolah Tinggi Keguruan dan Ilmu Pendidikan.

Anonim, 2004 ; Hidayati Milasari. 2010. "Uji efek antidiare Ekstrak etanol 50\% daun salam (Syzygium polyanthum (weight.) walp.) terhadap mencit jantan yang diinduksi oleoum ricini. Surakarta: Universitas Muhammadiyah Surakarta. 
Anief M, 1995 ; Yasnita, Khori. 2018. “ Uji Efek Antidiare Ekstrak Etanol Daun Laban (Vitex Quinata Lour.F.N. Williams) Terhadap Mencit Jantan “. Medan : Universitas Sumatera Utara.

Bitcher dan Lotterer, 1993 ; Hudayani Miftakhul. 2008. "Efek antidiare etanol rimpang kunyit (Curcuma dosmetica Val.) pada mencit jantan galurSwiss Webster". Surakarta : Universitas Muhammadiyah Surakarta.

Chitme, et al., 2004 ; Yasnita, Khori. 2018. “ Uji Efek Antidiare Ekstrak Etanol Daun Laban (Vitex Quinata Lour.F.N. Williams) Terhadap Mencit Jantan “. Medan : Universitas Sumatera Utara.

Daliamartha, 2006 ; Hidayati Milasari. 2010. ““Uji efek antidiare Ekstrak etanol 50\% daun salam (Syzygium polyanthum (weight.) walp.) terhadap mencit jantan yang diinduksi oleoum ricini.Surakarta : Universitas Muhammadiyah Surakarta.

Darmono, 2011 ; Yasnita, Khori. 2018. "Uji Efek Antidiare Ekstrak Etanol Daun Laban (Vitex Quinata Lour.F.N. Williams) Terhadap Mencit Jantan". Medan : Universitas Sumatera Utara.

DepKes RI. 1986 ; EM Sutrisna, M. Kes, 2016. "Herbal Medicine : Suatu tinjauan farmakologis". Surakarta : Muhammadiyah University Press.

DepKes RI. 1995. Farmakope Indonesia, Edisi IV. Jakarta: Departemen Kesehatan RI.

DepKes RI. 2000 ; Yasnita, Khori. 2018. “ Uji Efek Antidiare Ekstrak Etanol Daun Laban (Vitex Quinata Lour.F.N. Williams) Terhadap Mencit Jantan “. Medan : Universitas Sumatera Utara.

Di Carlo et.al., 1993 ; Yasnita Khori. 2018. “ Uji Efek Antidiare Ekstrak Etanol Daun Laban (Vitex Quinata Lour.F.N. Williams) Terhadap Mencit Jantan “. Medan : Universitas Sumatera Utara.

Ditjen POM, 1997 ; Yasnita, Khori. 2018. “ Uji Efek Antidiare Ekstrak Etanol Daun Laban (Vitex Quinata Lour.F.N. Williams) Terhadap Mencit Jantan “. Medan : Universitas Sumatera Utara.

Djuanda et.al., 2016 ; Yasnita, Khori. 2018. “ Uji Efek Antidiare Ekstrak Etanol Daun Laban (Vitex Quinata Lour.F.N. Williams) Terhadap Mencit Jantan “. Medan : Universitas Sumatera Utara.

EM Sutrisna, M. Kes, 2016. "Herbal Medicine : Suatu tinjauan farmakologis". Surakarta : Muhammadiyah University Press.

Fajaryanti, Nita dan Kurniawati, Nunik Ida. 2018. "Efek antidiare infusa daun ciplukan (physallis Angulata Linn) pada mencit jantan putih (Mus musculus) yang terpapar oleoum ricini”. Jurnal Farmasetis. Vol. 7 (1) : hal 19-22.

Farnsworth, 1966 ; Yasnita, Khori. 2018. "Uji Efek Antidiare Ekstrak Etanol Daun Laban (Vitex Quinata Lour.F.N. Williams) Terhadap Mencit Jantan “. Medan : Universitas Sumatera Utara.

Ganiswarma, 2007 ; Shaleh, Miftah Ulfah. 2016. "Uji efek antidiare ekstrak etanol daun kacang gude (Cajanus Cajan (L.) Milla sp) pada mencit (Mus musculus). Makassar : Universitas Islam Negeri Allaudin.

Hadi, 2002 ; Shaleh, Miftah Ulfah. 2016. "Uji efek antidiare ekstrak etanol daun kacang gude (Cajanus Cajan (L.) Milla sp) pada mencit (Mus musculus). Makassar : Universitas Islam Negeri Allaudin.

Hamita dan Radji, 2008 ; Yasnita, Khori. 2018. “Uji Efek Antidiare Ekstrak Etanol Daun Laban (Vitex Quinata Lour.F.N. Williams) Terhadap Mencit Jantan “. Medan : Universitas Sumatera Utara.

Hanani, Endang. 2015. "Analisis Fitokimia”. Jakarta : Buku Kedokteran, EGC.

Hariana, 2007 ; Fajaryanti, Nita dan Kurniawati, Nunik Ida. 2018. "Efek antidiare infusa daun ciplukan (physallis Angulata Linn) pada mencit jantan putih (Mus musculus) yang terpapar oleoum ricini”. Jurnal Farmasetis. Vol. 7 (1) : hal 19-22. 
Harborne, 1966 ; Yasnita, Khori. 2018. “ Uji Efek Antidiare Ekstrak Etanol Daun Laban (Vitex Quinata Lour.F.N. Williams) Terhadap Mencit Jantan “. Medan : Universitas Sumatera Utara.

Ide, Pangkalan. 2010. "Health Secret Of Pepino". Jakarta : PT Elrx Media Komputindo.

Ikawati, 2008 ; Yasnita, Khori. 2018. “ Uji Efek Antidiare Ekstrak Etanol Daun Laban (Vitex Quinata Lour.F.N. Williams) Terhadap Mencit Jantan “. Medan : Universitas Sumatera Utara.

Joko, Suryo. 2010. "Herbal penyembuh gangguan sistem pernafasan”. Jakarta : B First.

Kemenkes, RI. 2017. "Profil Kesehatan Indonesia. Jakarta : Kemenkes RI.

KKIPM, 1993 ; Yasnita, Khori, 2018. " Uji Efek Antidiare Ekstrak Etanol Daun Laban (Vitex Quinata Lour.F.N. Williams) Terhadap Mencit Jantan “. Medan : Universitas Sumatera Utara.

Kristina et.al., 2008 ; Yasnita, Khori. 2018. “ Uji Efek Antidiare Ekstrak Etanol Daun Laban (Vitex Quinata Lour.F.N. Williams) Terhadap Mencit Jantan “. Medan : Universitas Sumatera Utara.

Kusumawati, 2004 ; Fidzaro F, 2010. “ Pengaruh pemberian ekstrak biji klabet (Trigonella foenum graceum L) terhadap kadar glukosa darah dan gambaran histologi pankreas mencit (Mus musculus) yang terpapar Streptozotocin". Malang : Universitas Islam Negeri Maulana Malik Ibrahim.

Luterrdort, 1989 ; Yasnita, Khori. 2018. “ Uji Efek Antidiare Ekstrak Etanol Daun Laban (Vitex Quinata Lour.F.N. Williams) Terhadap Mencit Jantan “. Medan : Universitas Sumatera Utara.

Ma'arifin, 1993 ; Shaleh, Miftah Ulfah. 2016. "Uji efek antidiare ekstrak etanol daun kacang gude (Cajanus Cajan (L.) Milla sp) pada mencit (Mus musculus). Makassar : Universitas Islam Negeri Allaudin.

Malole, 1989 ; Shaleh, Miftah Ulfah. 2016. "Uji efek antidiare ekstrak etanol daun kacang gude (Cajanus Cajan (L.) Milla sp) pada mencit (Mus musculus). Makassar : Universitas Islam Negeri Allaudin.

Mansjeor et.al., 2001 ; Shaleh, Miftah Ulfah. 2016. "Uji efek antidiare ekstrak etanol daun kacang gude (Cajanus Cajan (L.) Milla sp) pada mencit (Mus musculus). Makassar : Universitas Islam Negeri Allaudin.

Marcellus, 2001 ; Hudayani Miftakhul. 2008. "Efek antidiare etanol rimpang kunyit (Curcuma dosmetica Val.) pada mencit jantan galurSwiss Webster". Surakarta : Universitas Muhammadiyah Surakarta.

MGMP. 2019. "Farmakologi Jilid II". Jakarta : PT Deepublish Publisher

Mukhriani, 2014 ; EM Sutrisna, M. Kes, 2016. "Herbal Medicine : Suatu tinjauan farmakologis". Surakarta : Muhammadiyah University Press.

Musdar, Tamzil Azizi, 2012. "Uji Aktivitas antidiare ekstrak etanol daun salam (Poliyanthi folium) pada mencut (Mus musculus) yang di induksi oleum ricini". Makassar : Universitas Islam Negeri Alauddin Makassar.

Mustchler, 1999 ; Yasnita, Khori. 2018. “ Uji Efek Antidiare Ekstrak Etanol Daun Laban (Vitex Quinata Lour.F.N. Williams) Terhadap Mencit Jantan “. Medan : Universitas Sumatera Utara.

Natalia C.L. 2014. "Imunomodulator, Imunosupresan dan Imunostimulan. Dalam: Farmakologi dan Terapi". Edisi Kelima. Jakarta: Balai Penerbit FKUI.

Praja, Indra Renny. 2015. "Zat Aditif Makanan, Manfaat Dan Bahaya". Yogyakarta : Garudhawaca.

PGHNAI. 2014. "Kumpulan Makalah". Bali : Ikatan Dokter Indonesia.

Sardjono et.al., 2004 ; Hudayani Miftakhul. 2008. "Efek antidiare etanol rimpang kunyit (Curcuma dosmetica Val.) pada mencit jantan galurSwiss Webster". Surakarta : Universitas Muhammadiyah Surakarta.

Setijo, Pijoto. 2002. "Ceplukan, Herbal berkhasiat obat". Jakarta : Kansius 
Seogijanto, 2004 ; Fajrin Fifteen Aprillia. 2002."Aktivitas Antidiare Ekstrak Etanol Daun Seledri (Apium Graveolens L) Pada Mencit Jantan”. Jurnal Pharmacy Indonesia. Vol. 09 (01) : hal 2-8.

Smith, 1988 ; Shaleh, Miftah Ulfah. 2016. "Uji efek antidiare ekstrak etanol daun kacang gude (Cajanus Cajan (L.) Milla sp) pada mencit (Musmusculus). Makassar : Universitas Islam Negeri Allaudin.

Sugianto, 2008 ; Yasnita, Khori. 2018. “ Uji Efek Antidiare Ekstrak Etanol Daun Laban (Vitex Quinata Lour.F.N. Williams) Terhadap Mencit Jantan “. Medan : Universitas Sumatera Utara.

Sukandar, 2008 ; Fajaryanti, Nita dan Kurniawati, Nunik Ida. 2018. "Efek antidiare infusa daun ciplukan (physallis Angulata Linn) pada mencit jantan putih (Mus musculus) yang terpapar oleoum ricini”. Jurnal Farmasetis. Vol. 7 (1) : hal 19-22.

Sulaiman et.al., 1990 ; Shaleh, Miftah Ulfah. 2016. "Uji efek antidiare ekstrak etanol daun kacang gude (Cajanus Cajan (L.) Milla sp) pada mencit (Mus musculus). Makassar : Universitas Islam Negeri Allaudin.

Syahrin, 2006 ; Fidzaro F, 2010. "Pengaruh pemberian ekstrak biji klabet (Trigonella foenum graceum L) terhadap kadar glukosa darah dan gambaran histologi pankreas mencit (Mus musculus) yang terpapar Streptozotocin”. Malang : Universitas Islam Negeri Maulana Malik Ibrahim.

Tan, 2002 ; Musdar, Tamzil Azizi, 2012. "Uji Aktivitas antidiare ekstrak etanol daun salam (Poliyanthi folium) pada mencut (Mus musculus) yang di induksi oleum ricini”. Makassar : Universitas Islam Negeri Alauddin Makassar.

Tan dan Kirana, 2007 ; Yasnita, Khori. 2018. “ Uji Efek Antidiare Ekstrak Etanol Daun Laban (Vitex Quinata Lour.F.N. Williams) Terhadap Mencit Jantan “. Medan : Universitas Sumatera Utara.

Tarannita Citra et al., 2006. "Efek Hambatan Ekstrak Daun Ciplukan (physallis minima L) tergadap kontraktilitas otot polos usus halus terpisah marmut dengan stimulasi metrakolin eksogen". Jurnal Kedokteran brawijaya. Vol. 22 (1) : hal 18-23.

Thripati, 2008 ; Yasnita, Khori. 2018. “ Uji Efek Antidiare Ekstrak Etanol Daun Laban (Vitex Quinata Lour.F.N. Williams) Terhadap Mencit Jantan “. Medan : Universitas Sumatera Utara.

Tjay dan Raharja, 2002 ; Hudayani Miftakhul. 2008. "Efek antidiare etanol rimpang kunyit (Curcuma dosmetica Val.) pada mencit jantan galurSwiss Webster". Surakarta : Universitas Muhammadiyah Surakarta.

Tjay dan Raharja, 2010 ; Fajaryanti, Nita dan Kurniawati, Nunik Ida. 2018. "Efek antidiare infusa daun ciplukan (physallis Angulata Linn) pada mencit jantan putih (Mus musculus) yang terpapar oleoum ricini”. Jurnal Farmasetis. Vol. 7 (1) : hal 19-22.

Tranggono dan Latifa. 2013. "Buku Pegangan Ilmu kosmetik". Jakarta : PT. Gramedia Pustaka utama

Rang et al, 2007 ; Yasnita, Khori. 2018. “ Uji Efek Antidiare Ekstrak Etanol Daun Laban (Vitex Quinata Lour.F.N. Williams) Terhadap Mencit Jantan “. Medan : Universitas Sumatera Utara.

Weinberg, Alan., Bealer K. Bonnie. 2002. "The miracle of caffeine”. diterjemahkan oleh warastuti. Jakarta : Penerbit Qanita.

Widjayanto dan Nurhidayat. 2017. "BIOINDUSTRI". Malang : UB Press.

Wiryondagdo, 2007 ; Musdar, Tamzil Azizi, 2012. "Uji Aktivitas antidiare ekstrak etanol daun salam (Poliyanthi folium) pada mencut (Mus musculus) yang di induksi oleum ricini". Makassar : Universitas Islam Negeri Alauddin Makassar.

Yatim, Raisal. 2000. "Jantung Koroner Stroke Meninggal Mendadak atasi dengan pola hidup sehat". Jakarta : Pustaka Populer. 